\title{
Legal Status Of THE Honorary CONSUl
}

\author{
MIROSEAW DELA*
}

\section{INTRODUCTION}

In addition to the consular service, consisting of officials exercising their functions professionally, the practice has developed of appointing socalled honorary consuls ${ }^{1}$, who are not permanent officials of the sending State and do not receive remuneration ${ }^{2}$. This institution has its roots in the ancient Greek proxen $^{3}$, who exercised custody of foreign nationals without remuneration ${ }^{4}$. The development of the institution of honorary consul took place in the nineteenth and twentieth centuries ${ }^{5}$. It proved to be

DOI: 10.1515/wrlae-2015-0007

*Ph.D candidate at Department of Business and Commercial Law, Faculty of Law, Administration and Economics, Wroclaw University; miroslaw.dela@prawo.uni.wroc.pl.

${ }^{1}$ The title of honorary consul (consul honorarius) has been granted by the emperor since Roman times, but is not connected with the exercise of any specific official functions, Julian Sutor, Leksykon dyplomatyczny (Warsaw 2010) 217.

${ }^{2}$ Honorary consuls usually serve without salary, and are only offered reimbursement for some of their expenses, Kevin D. Stringer, 'Honorary Consuls in an Era of Globalization, Trade, and Investment' in Jan Melissen, Ana Mar Fernández (eds), Consular Affairs and Diplomacy (Leiden 2011) 76. They may, however, in contrast to the career consuls conduct other gainful activity. See Wojciech Góralczyk and Stefan Sawicki, Prawo międzynarodowe publiczne $w$ zarysie (Warsaw 2009) 288 and 289.

${ }^{3}$ Proxenos, proxen (Greek: for guest, host) - in ancient Greece, a polis citizen acting as a guardian for newcomers from another polis. He was not a messenger of the State whose citizens he helped. For more about proxen see Sebastian Sykuna and Jerzy Zajadło, Leksykon prawa i protokotu dyplomatycznego - 100 podstawowych pojęć (Warsaw 2011) 148. About permission for proxen to represent aliens before assemblies to local authorities and the courts see Izabela Gawłowicz, Międzynarodowe prawo dyplomatyczne - wybrane zagadnienia (Warsaw 2011) 148.

${ }^{4}$ More about the origins of the institution of consul in Stefan Sawicki, Prawo konsularne. Studium prawnomiędzynarodowe (Warsaw 2003) 21. From 242 BC, there was also in Rome the function of praetor for foreigners (praetor peregrinus), dealing with issues of immigration to Rome. For more about the office of praetor see Witold Wołodkiewicz and Maria Zabłocka, Prawo rzymskie. Instytucje (Warsaw 1996) 71 and 286.

${ }^{5}$ For more on the development of the institution of honorary consul see Paweł Czubik and Michał Kowalski, Konsul honorowy. Studium prawnomiędzynarodowe (Zakamycze 1999) $17 \mathrm{ff}$. 
particularly necessary when, for political, financial or staffing reasons the sending State had no diplomatic representative or career consular officer ${ }^{6}$. In other cases, he complimented the role of the professional consul ${ }^{7}$.

However, recognition of the institution of honorary consul is not an obligation. In the past, most of the former socialist countries, including Poland, did not take advantage of this institution ${ }^{8}$. Currently, Poland has 221 foreign honorary consular offices in 106 countries (206 honorary consuls) ${ }^{9}$. In Poland there are 165 consular posts headed by honorary consuls from 58 countries (166 honorary consuls) ${ }^{10}$

The legal status of honorary consuls is a bit different than that of career consular officers, which manifests itself inter alia in the narrower range of privileges and immunities they enjoy. They perform their duties based on a specific act of appointment by the ministry of foreign affairs of the sending State, which contains the scope of their assigned tasks. This scope may be broad - similar to the tasks of a professional consul, or narrow - sometimes only symbolic ${ }^{11}$. This is dependent on the specifics of the interests of the state involved, as well as the consent of the consul. Regulations concerning the organization of consular services can be found not only in the provisions of international law, but also in the internal regulations of the sending State, which are often elaborated in detailed instructions. Of importance are also the norms of customary law and bilateral consular agreements concluded between the sending State and the receiving State.

\footnotetext{
${ }^{6}$ Gawłowicz (n 3) 150. These days, however, the institution of honorary consul also provides a mechanism to overcome limited financial and human resources. It seems to be a valuable tool used principally by small to medium-sized countries (especially by developing nations) to improve leverage over local or regional business development opportunities. Consulates, even more than embassies, are therefore becoming the lifeblood of modern diplomacy. Stringer (n 2) 94. Some microstates rely almost entirely on consular representation for their links to the outside word. For such states the institution of honorary consul is an economical means of achieving representation on a scale otherwise unlikely, Stringer (n 2) 77 and 78.

${ }^{7}$ Sutor, Leksykon dyplomatyczny (n 1) 217.

${ }^{8}$ Góralczyk and Sawicki (n 2) 289. See also Polish experience of care in favorem tertii, Paweł Czubik, Prawo dostęu do konsula (Instytut Europejski UJ, Krakow 2011) 309.

${ }^{9}$ Data from the Ministry of Foreign Affairs of Poland as of 03 Feb 2014 (the difference between the number of honorary consuls and consular offices results from vacancies).

${ }^{10}$ Data from the Ministry of Foreign Affairs of Poland as of 31 Jan 2014.

11 The procedure for the appointment and dismissal of an honorary consul and a career consul, levels, and to a large extent also their functions are all convergent. Honorary consuls usually do not have permission to issue visas and passports, Sutor, Leksykon dyplomatyczny (n 1) 218 and Julian Sutor, Prawo dyplomatyczne $i$ konsularne (Warsaw 2012) 507 and 508. As a rule, an honorary consul cannot perform a function in which it is necessary to use state power, for example, act as a registrar or a notary. See Sykuna and Zajadło (n 3) 150. See also on marine and commercial consuls who serve as judges in commercial disputes Gawłowicz (n 3) 148. The character of an honorary consul should be interpreted according to tradition. Typically, consular officers have two primary tasks: firstly, to develop economic, scientific and cultural relations between countries (especially promoting commerce in both directions); secondly, to safeguard the interests of the sending state and its citizens. However, functions of the honorary consul can be often expanded or reduced according to the needs of service,Stringer (n 2) 65.
} 


\section{CONVENTIONAL REgUlations ON THE OPERATION OF HONORARY CONSULS AND HONORARY CONSULAR OFFICES THEY LEAD}

In 1963 the Diplomatic Conference in Vienna adopted the Vienna Convention on Consular Relations. This document is the foundation of the institution of honorary consul ${ }^{12}$.

The Convention divides consular officers into two categories - career and honorary (Article 1 par 2) $)^{13}$. Chapter III of the Convention contains provisions relating to honorary consular officers and consular offices led by them. Although the division is formally recognized, Art. 58 requires the direct application to honorary consular offices and officers of many provisions of the Convention relating to professional offices and consular officials, thereby aligning their rights of access to many facilities, privileges and immunities ${ }^{14}$. The right to use the flag and emblem of the sending State, which can be displayed on the building occupied by the consular post and on its means of transport as long as they are used for official purposes, is the same (Article 29). The receiving State must facilitate the obtaining of premises necessary in the work of the consular office and housing for the members of the office (Article 30), to ensure that all members of the consular office have freedom of movement and travel in the territory of the receiving State (Article 34) and freedom of communication for official purposes, including the use of diplomatic or consular couriers, diplomatic or consular post and sending of correspondence done in code or cipher ${ }^{15}$. The official correspondence of the consular office is inviolable (Article 35). The freedom of communication of honorary consuls with the

\footnotetext{
12 Journal of Laws 1982, no 13, item 98 (appendix). The Convention was opened for signature on 24 April 1963, entered into force on 19 March 1967, ratified by Poland 17 Sept 1981. The bilateral consular agreements constitute lex specialis in relation to the Convention. Nothing in this Convention shall affect international agreements concluded between the parties. It shall not prevent a state from concluding agreements reaffirming, supplementing or extending its provisions or scope of application. See Góralczyk and Sawicki (n 2) 285.

${ }^{13}$ Consular officers had not been subject to this division officially until the nineteenth century, Gawłowicz (n 3) 148. The author also details the differences between honorary and career officials, associated with the requirement of career consul citizenship from the sending State, and the requirement to remaining in a service relation, Gawłowicz (n 3) 151 ff.

14 See more Stefan Sawicki, Przywileje $i$ immunitety konsularne. Studium prawno międzynarodowe (Ossolineum 1989) 191 ff. The author points to the possibility of differentiating advantages in the sense that the privileges of honorary consuls having the nationality of the sending State or a third country are much broader compared to those afforded to a consular officer who is a national of the receiving State (p. $202 \mathrm{ff}$ ). The author stresses the universal tendency to escalate privileges and immunities of consular representations and their gradual leveling of diplomatic privileges and immunities. They currently cover the whole territory of the host country, not just the consular district, as it was in the past. It expands their range of subjective discretion, and they enjoy a broader range of employees at the consular post, not just the head office, but also administrative staff, technical service staff of the consular post, and sometimes even family members of officials and employees (p. 209). On the same subject see also Sawicki (n 4) 289 ff. and Gawłowicz (n 3) 157. On the division between property and personal privileges see Czubik and Kowalski (n 5) $101 \mathrm{ff}$.

${ }^{15}$ With some restrictions on the installation of radio transmitters.
} 
authorities of the receiving State must be guaranteed (Article 38 ), but also with the citizens of the sending State, as well as the possibility of free access to them, which is of particular importance in the case of the arrest of a foreigner (Article 36). An honorary consul should also be informed by the competent authorities of the receiving State about the death of a national of the sending State, the need to establish a guardian or a curator, as well as about the disasters of ships or aircrafts belonging to the sending State (Article 37). Fees and other consular duties charged by an honorary consul are exempt from all dues and taxes in the receiving State (Article 39).

In case of arrest, pre-trial detention or criminal proceedings against the head of an honorary consular post or of a member of the consular staff, the Convention imposes on the receiving State the same obligation to inform the sending State as in the case of detention of a head or member of staff of a career consulate (Article 42). Immunity is treated in the same manner, which applies only to activities related to the exercise of consular functions (Article 43 and 53) ${ }^{16}$. The honorary consul is also exempted from the obligation to give evidence concerning matters connected with the exercise of consular functions and to present official correspondence and documents (Article 44 par 3). The sending State may issue an express waiver of rights resulting from Articles 43 and 44 par 3 (Article 45). Article 55 par 1 undertakes to exercise the powers under the preceding provisions with respect to the internal rules of the receiving State. The privileges and immunities provided for in the Convention are not extended to the family members of an honorary consular officer nor employees of the honorary consulate (Article 58 par 3).

The exchange of consular bags between two honorary consular posts in different States is permitted only with the consent of the two receiving States (Article 58 par 4).

The receiving State shall take all necessary measures to protect the consular premises of an honorary consular post against intrusion or damage and to prevent disturbance of the peace of the consular post or impairment of its dignity (Article 59). Honorary consular premises are exempted from any dues and taxes if the owner or tenant of the premises is the sending State (Article 60) ${ }^{17}$

Article 61 provides for the inviolability of consular archives and documents, regardless of the time and place in which they are located, provided that they are separated from other documents such as personal correspondence and documents related to the professional activities and trade of the consul and his associates. The receiving State shall permit entry of and grant exemption from customs duties and taxes to such items as the emblem, flags, signs, stamps, books, official printed matter, furniture, office equipment and similar articles supplied for the consular post by the sending State or on its behalf, provided that they are intended solely for the official use of the honorary consular post (Article 62).

\footnotetext{
${ }^{16}$ Immunity from jurisdiction is purely functional and not personal (so the function is protected but not the person performing this function), Góralczyk and Sawicki (n 2) 291. Honorary consuls are not provided with the personal immunity referred to in Article 41.

${ }^{17}$ The exemption does not apply to fees payable for the provision of certain services, as well as dues and taxes under the provisions of the receiving State of the person who contracted with the sending State.
} 
Article 63 requires an honorary consular officer to appear before the competent authorities if criminal proceedings are instituted against him. It also requires, however, the officers of the receiving State to carry out this procedure with the respect due to him because of the functions of the position, and in a manner which will hamper the exercise of consular functions as little as possible. Article 64 imposes an obligation on the receiving State to accord to an honorary consular officer the necessary protection.

In accordance with Article 65, honorary consular officers are exempt from obligations provided for in the regulations of the receiving State for the registration of aliens and residence permits ${ }^{18}$. Article 66 exempts an honorary consular officer from dues and taxes on the remuneration and emoluments which he receives from the sending State in the exercise of consular functions. Article 67 requires that the receiving State exempt honorary consular officers from all personal services, including public service and the burden of defence of the receiving State.

Article 68 gives each state the freedom to decide on the appointment or receiving honorary consular officers. This means that the institution of honorary consul is an optional one ${ }^{19}$.

\section{Honorary Consulates of POLANd ON THE TERritory OF FOREIGN STATES}

Alongside the norms of international law, the norms of internal law also regulate the organization of the consular services of particular States, complementing and extending provisions of the Convention concerning the legal status of consular posts and individuals associated with them. In respect of Polish practice, the activity of consuls sent by Poland to other countries is governed by the Act of 13 February 1984 on the functions of consuls of the Republic of Poland ${ }^{20}$, and secondary legislation issued on its basis, including the Regulation of the Minister of Foreign Affairs of 7 December 2006 on honorary consuls of the Republic of Poland ${ }^{21}$.

\section{a) Statutory regulations}

The functioning of honorary consuls is addressed briefly by Article 5 of the Act on functions of consuls of the Republic of Poland ${ }^{22}$, while

\footnotetext{
18 This exemption does not apply to those officials who perform professional or commercial activity in the host country for personal profit.

${ }^{19}$ Góralczyk and Sawicki (n 2) 289.

${ }^{20}$ In Polish: Ustawa z 13.02.1984 o funkcjach konsulów Rzeczypospolitej Polskiej (Journal of Laws 1984, no 9, item 34).

${ }^{21}$ In Polish: Rozporządzenie Ministra Spraw Zagranicznych z 7.12.2006 r. w sprawie konsulów honorowych Rzeczypospolitej Polskiej (Journal of Laws 2006, no 239, item 1735).

22 See changes made to the law cited by Article 25(1) of the Act of 22 Dec 2000 amending certain statutory authorization to issue normative acts and amending certain acts (in Polish: Ustawa $\mathrm{z}$ 22.12.2000 o zmianie niektórych upoważnień ustawowych do wydawania aktów normatywnych oraz o zmianie niektórych ustaw) (Journal of Laws 2000, no 120 , item 1268).
} 
granting the Minister of Foreign Affairs a statutory delegation to issue a secondary act elaborating the provisions of the statute (Article 5 (7)).

The power to appoint honorary consuls general, consuls, viceconsuls and consular agents to perform some of the functions of consuls is assigned to the minister responsible for foreign affairs (Article 5(1)). This function can be entrusted by appointment to Polish citizens residing in the receiving State, as well as citizens of the receiving State and of third countries. The candidate must enjoy the respect and trust of society, and provide a guarantee of the exercise of functions in accordance with the interests of the Republic of Poland and its citizens (Article 5(2)). In the appointment letter, the minister establishes the consular district and scope of the honorary consul's functions (Article 5(3) $)^{23}$. In terms of the functions performed, the honorary consul is subordinate to the head of the diplomatic mission, and the direct supervision of his activities is performed by the career consul with jurisdiction over the relevant territory (Article 5 (5) and Article 5 (6)).

\section{b) Delegated legislation}

The Regulation of the Minister of Foreign Affairs of 7 December 2006 on Polish honorary consuls lays down the detailed procedure for the appointment and dismissal of honorary consuls ${ }^{24}$, principles and scope of the exercise of their functions, their interactions with career consuls, how to bear the cost of their service, as well as cases in which they cease to perform their functions $(\S 1)$.

In accordance with $\S 3(1)$ individuals with full legal capacity may be appointed honorary consuls, with the prior consent of the receiving State (the so-called exequatur) ${ }^{25}$. Such authorization is requested by the head of the territorial competent diplomatic mission in consultation with the Minister of Foreign Affairs (\$3(2)).

The head of the territorially competent diplomatic mission asks the Minister of Foreign Affairs to request the establishment of an honorary consular office and to appoint an honorary consul $(\S 4(1))$. The request includes a proposal for the rank of the office, the seat and the consular district, and also indicates the candidate for the position of honorary consul along with the proposed scope of his functions. It also indicates the territorially competent career consul who will exercise direct supervision over the activities of the honorary consul. The application should be accompanied by a justification, curriculum vitae and two photographs of the candidate $(\S 4(2))$.

\footnotetext{
${ }^{23}$ The consular district and range of functions specified in the appointment can be changed with the consent of the consul by the minister responsible for foreign affairs (Article 5(4)).

24 This should be understood as an honorary consul general, honorary consul, honorary vice-consul and honorary consular agent $(\$ 2(1))$.

25 Exequatur - the consent of the receiving State to perform by a specific person the function of head of the consular post of the sending State. It may also apply to other consular officials. A State refusing to grant an exequatur is not obliged to give reasons for its refusal. The date of delivery of the exequatur determines priority (precedence) under the so-called the consular corps. See the twin concept of agrément in diplomatic law.
} 
An honorary consul is appointed by the minister responsible for foreign affairs for a period of five years $(\S 5(1))^{26}$. An honorary consul ceases to perform his functions in the event of withdrawal of consent to act by the receiving State, in the event the honorary consul submits a written resignation ${ }^{27}$ which is then accepted by the minister responsible for foreign affairs, as well as in the event of being recalled by the minister responsible for foreign affairs at the request of the head of the territorially relevant diplomatic mission. This proposal must be consulted with the territorially competent career consul $(\S 6(1))$. Its basis may be a negative evaluation of the activities of an honorary consul, or other valid reasons $(\S 6(2))$. The head of the territorially competent diplomatic mission notifies the receiving State about the cessation of the functions of an honorary consul $(\S 6.3)^{28 .}$

The consular district of an honorary consular post cannot encompass the municipality which serves as the seat of a consular post headed by a career consul $(\S 7)$. An honorary consul takes action in his consular district to promote and develop friendly relations and cooperation between Poland and the receiving State, as well as the protection of the rights and interests of the Republic of Poland and its citizens in the receiving State. Consular activities also have as their objective to strengthen ties between Poland and the Polish community living in the receiving State, as well as to enhance economic, cultural, scientific and technical cooperation $(\S 8(1))$.

In the exercise of consular functions, the honorary consul interacts with the territorially competent head of the diplomatic mission and the career consul; in particular, he presents annual plans of activity for consultation, informs about matters and events important from the consular point of view, notifies of breaks in operation of the business office, announces the working hours of the office and workers employed therein ( $\S$ $8(2))$.

The duty of the honorary consul is to present an annual report on the activity conducted by his office to the head of the territorially competent diplomatic mission, via the territorially competent career consul $(\S 8(3)$ ). The activities of the honorary consul are subject to annual evaluation by the head of the territorially competent diplomatic mission, after obtaining the opinion of the territorially competent career consul $(\S 8(4))$. The honorary consul performs consular functions entrusted to him without prejudice to his professional activity ( $(9)$, which means that he can for example run a business or be employed.

It is required that the honorary consular postal documents and archives be separated from other documents, in particular from the private

\footnotetext{
${ }^{26}$ The head of the territorially competent diplomatic mission, after receiving a favorable opinion from the territorially competent career consul, not later than one month before the expiry of the term of office of an honorary consul may request the minister responsible for foreign affairs for an extension of the function of honorary consul for another 5 years ( $\S$ $5(2)$ ).

${ }^{27}$ Resignation may be made directly to the minister or through the head of the territorially competent diplomatic mission.

${ }^{28}$ More information on the beginning and end of the function of honorary consul see Sutor, Prawo dyplomatyczne i konsularne (n 11) 522. The final step towards the establishment of an honorary consul is the ceremonial presentation of the documents of appointment (nomination and exequatur) by a representative of the Ministry of Foreign Affairs. See Gawłowicz (n 3) 154 and 155.
} 
correspondence of the honorary consul and from documents related to his professional activities $(\S 10)$.

In the exercise of his functions the honorary consul receives no compensation, and he does not acquire any rights provided by Polish legislation in the fields of labour law and social security law (§ 11). In addition, the honorary consul shall bear the costs associated with the exercise of consular functions, which include occupancy costs, equipment and maintenance of the office, staff employed, fees, taxes and other benefits of public law (§ 12(1)). The minister responsible for foreign affairs provides the honorary consul with only the flag and emblem of Poland and a plate with the name of the office, installed on its premises, as well as ensures the supply of materials and other information deemed by him to be necessary for the exercise of consular functions (§ 12(2) and (3)).

\section{HONORARY CONSULATES OF OTHER COUNTRIES ON THE TERRITORY OF THE REPUBLIC OF POLAND}

In the "Guide for foreign diplomatic missions accredited in Warsaw $^{\prime 29}$ there are issues discussed related to the establishment of a new consular office, the conditions to be met by a candidate for honorary consul $^{30}$, the procedure for admission of honorary consul to the function, withdrawal of exequatur and the status of honorary consuls and the consular offices operated by them in Poland.

The establishment of a new honorary consular office of a foreign country in the Republic of Poland takes place according to the rules provided for by the Vienna Convention on Consular Relations of 1963 for the establishment of a consular post headed by a career consular officer ${ }^{31}$.

The consular district of an honorary consular post may cover the territory of one or more voivodeships, or the entire Republic of Poland. In the case of an honorary consul general, this district should encompass an area of at least three voivodeships. Consular districts cannot overlap, and the seat of an honorary consular office should be a voivodeship capital ${ }^{32}$. It cannot, however, be in a city in which diplomatic missions or career consular posts have their seat. In the event the sending State has no diplomatic representation in Poland ${ }^{33}$ and the territorial scope of the honorary consular post would cover the entire territory of the Republic of Poland, the seat of the office should be located in Warsaw ${ }^{34}$. There may be

\footnotetext{
${ }^{29}$ The Guide is not a publication for the public. The author used fragments of the guide provided by the Diplomatic Protocol of the Ministry of Foreign Affairs of Poland (11 Feb 2014). The guidance is a sui genesis instruction addressed to the representatives of diplomatic missions and consular services of foreign states on the territory of Poland.

${ }^{30}$ Whenever this guide refers to an honorary consul, it should be understood as an honorary consul general, honorary consul, honorary vice-consul and honorary consular agent.

${ }^{31}$ Establishment in Poland of an honorary consular office and the procedure for admission of the head of the office to perform its functions takes into account bilateral consular agreements concluded by Poland with a number of countries, in addition to the provisions of the Convention.

${ }^{32}$ Exceptions to this rule are allowed only in particularly justified cases.

${ }^{33}$ Likewise, in situations where there is a diplomatic mission with permanent residence in another state.

${ }^{34}$ Exceptions to this rule are allowed only in particularly justified cases.
} 
no branch of an honorary consular office. The staff of an honorary consular office may also consist of career consular officials.

The establishment of an honorary consular office and permission for the head of the consular post to exercise his functions requires the prior approval of Polish authorities. Such authorization is requested by an appropriate diplomatic representative and, in the event that there is no such person, authorization is requested by the ministry of foreign affairs of the sending State by way of a note to the Ministry of Foreign Affairs of the Republic of Poland; this note specifies the location of the seat of the office, consular district and the status of the honorary head of the office ${ }^{35}$. The Ministry of Foreign Affairs of the Republic of Poland issues a note informing the applicant of its decision.

A candidate for honorary consul should be at least 25 years old and have full legal capacity, and should be a Polish citizen or a national of the sending State or a third country ${ }^{36}$. He must be a resident of the voivodeship in which the seat of his consular office is located, and he should enjoy a good reputation. His financial situation and social position must permit the independent and impartial exercise of his functions. He therefore may not perform any public functions in the Republic of Poland by nomination or election. He must also demonstrate long-term bonds linking him with the sending State.

After obtaining the approval of the competent authorities of the Republic of Poland for the establishment of an honorary consular office, a diplomatic representative of the sending State writes a note to the Ministry of Foreign Affairs of Poland of acceptance for a particular candidate for honorary consul ${ }^{37}$, giving his full name, nationality ${ }^{38}$, occupation, place of residence and proposed place of head office. The note is accompanied by the candidate's curriculum vitae. A reply with the decision of the Ministry of Foreign Affairs of Poland is sent in the form of a note to the diplomatic representative of the applicant. In the case of a positive decision, the sending State shall submit commission letters (fr. lettres de provision) ${ }^{39}$ bearing a description of the consular district headed by the candidate to be approved, signed by the Head of State or Minister of Foreign Affairs of the sending State or by another authorized person.

An honorary consul may exercise his functions for an undetermined or fixed length of time, depending on the will of the sending State. On the basis of commission letters bearing the appropriate signature, stamp, date and place of issue, the Minister of Foreign Affairs of the Republic of Poland

\footnotetext{
${ }^{35}$ In accordance with Article 9 of the Vienna Convention.

${ }^{36}$ In the case of not having Polish citizenship, the candidate must have a permit to settle in Poland.

${ }^{37}$ It is allowed to ask simultaneously for permission to establish a consular office and acceptance of the proposed candidate for honorary consul.

${ }^{38}$ If the candidate is a person who is not a Polish citizen permanently residing in the Republic of Poland, the note must be accompanied by a certified copy of a permit to settle in Poland and confirmation of permanent residence in Poland.

${ }^{39}$ It is a document under which the sending State shall appoint a person to the head of the consular post in the receiving State. The form of acceptance of a commission by the receiving State is an exequatur. See their equivalent - letters of credence (credentials) in diplomatic law (fr. lettres de créance).
} 
grants exequatur to the consul for performing his functions ${ }^{40}$. The honorary consular office should commence operations within three months from the date of delivery of the exequatur ${ }^{41}$. If within three months after receiving of exequatur the honorary consul does not start to exercise his functions, the consular office is revoked. The same applies if the position of honorary consul is vacant and a new candidate is not proposed within three months.

The Diplomatic Protocol staff of the Ministry of Foreign Affairs of Poland issues the honorary consul a consular ID card at the request of the diplomatic mission of the sending State ${ }^{42}$. Data on the honorary consular office and its head are posted on the "List of Diplomatic and Consular Corps" published on the website of the Ministry of Foreign Affairs of Poland.

Any change in the status ${ }^{43}$ of an honorary consular office requires prior approval of the Ministry of Foreign Affairs in Poland. To this end, the diplomatic mission of the sending State directs a note with a justification for the change.

An honorary consul can have his authorization to exercise his functions revoked in the event of a serious breach of the law in force in the Republic of Poland or of the provisions of the Vienna Convention on Consular Relations of 1963.

The diplomatic mission of the sending State shall exercise supervision over the activities of the honorary consul and determines in consultation with the Ministry of Foreign Affairs of Poland all matters relating to his status and scope, as well as the exercise of his privileges and immunities. The honorary consul and consular led by him shall enjoy facilities, privileges and immunities under Chapter III of the Vienna Convention on Consular Relations of 1963 (Articles 29, 43, 61), which were mentioned above. Excluded are the tax and customs privileges, except for those relating to the items listed in Article 62 of the Convention. Honorary consuls are advised not to affix "CC" (fr. Corps consulaire) on means of transport, and their vehicles are registered according to the general rules of the Republic of Poland.

\section{CONCLUSION}

The above analysis shows that the provisions of the Convention have been implemented into Polish law. Provisions of national law are consistent with the Convention, at times constituting its literal repetition.

\footnotetext{
${ }^{40}$ Permits shall be granted only to the honorary head of the consular post.

${ }^{41}$ The diplomatic mission of the sending State shall inform the Ministry of Foreign Affairs of Poland by a note, which should include information about the dates and opening hours of the office.

${ }^{42}$ Consular ID cards are also received by other honorary consular officers of a consular office. Members of their families are not entitled to such a card.

${ }^{43}$ Change may refer to the class of office (from vice-consulate to consulate or vice versa), or its character (from honorary office to career office). Raising or lowering the consular class involves a change in class of its honorary head and the need to submit new letters of commission and obtain a new exequatur. Changing the nature of the consular office also entails the need to again perform all the steps provided for in the procedure of admission of the head of a consular post for the exercise of its functions.
} 
In addition to the traditional functions of an honorary consul in the field of culture, promotion, trade and economy, expressed explicitly in the legislation discussed above, one may say the most important activity is to ensure care and legal assistance for nationals of the sending State, as well as informational activities ${ }^{44}$ (such as in the field of tourism). Honorary consuls can also perform other certain actions as ordered (passport, notary) ${ }^{45}$. The needs of individual consular districts are strongly differentiated, and the nature and extent of the functions performed by honorary consuls is often determined ad $\mathrm{casu}^{46}$.

Usually, the sending States are reluctant to contribute to the costs associated with the establishment and activity of an honorary consular office. The person acting as the head of such an office finances consular activities from his own pocket. Only in exceptional cases he can count on the return of a portion of expenses ${ }^{47}$. Therefore, the functions of honorary consuls are usually performed by people enjoying not only authority, but also wealth ${ }^{48}$. This does not mean, however, that it does not benefit the honorary consul. Often, businessmen, industrialists and other representatives of the economic elite decide to become an honorary consul, thinking that it will give them special social status and prestige ${ }^{49}$. Performing this function undoubtedly provides the possibility of additional contacts with representatives of the political establishment, and increases the credibility of the consul in the business world ${ }^{50}$.

The institution of honorary consul, however, gives rise to many controversies. This function is often exercised by the citizen of the receiving State, which may raise concerns about a lack of loyalty to the sending State. However, this means that the honorary consul knows the local customs, the specifics of local institutions, and enjoys a reputation and authority in the local community necessary for effective performance of his tasks. A positive aspect of honorary consuls is the fact that they have been instrumental in contributing to the development of contacts between societies, promoting culture, arts and tourism, as well as assisting in liaising with international business contacts. An honorary consul can engage with economic partners, e.g. local enterprises, business associations, as well as politicians, academics, representatives of the media, etc. In this way, a local honorary consular post can play a key role in developing export while

\footnotetext{
${ }^{44}$ Sutor, Prawo dyplomatyczne i konsularne (n 11) 508. Moreover, honorary consuls have also an important role to play in the context of transnational issues of the contemporary multipolar world, such as immigration, refugees, crimes, terrorism, ethnic conflicts, globalization, etc. Striger (n 2) 69. More about other advantages, as well as commercial viability and functional flexibility (ability to perform multiple roles), see Stringer (n 2) 66 ff.

${ }^{45}$ Sutor, Prawo dyplomatyczne i konsularne (n 11) 509.

${ }^{46}$ Gawłowicz (n 3) 152.

${ }^{47}$ Sutor, Leksykon dyplomatyczny (n 1) 217. Some compensation is the possibility to charge consular fees and to receive from the sending State partial or total reimbursement of expenses associated with maintaining the consulate, Góralczyk and Sawicki (n 2) 289.

${ }^{48}$ Sutor, Leksykon dyplomatyczny (n 1) 218. See Stringer (n 2) 63.

${ }^{49}$ Góralczyk and Sawicki (n 2) 289. The attractiveness of the posting for the position is that the prestige afforded by consular designation can be profitable in private business. Stringer (n 2) 77.

${ }^{50}$ Sutor, Prawo dyplomatyczne i konsularne (n 11) 509.
} 
providing a unique instrument for investment promotion ${ }^{51}$. Not without significance is the performance of the role honorary consul without remuneration. Opponents accuse the institution of honorary consul of an excess of ceremony, as well as honorary consuls of acting in order to enhance their own prestige, using their function to camouflage the economic benefits associated with their professional activities (such as customer acquisition), which in turn leads them to neglect consular duties. Honorary consuls are accused of a lack of the professionalism necessary for career consuls, who undergo special training. Therefore, some countries do not make use of the institution of honorary consul ${ }^{52}$.

\footnotetext{
${ }^{51}$ See more details Stringer (n 2) 92-94, especially the new term 'commercial diplomacy' used by Michel Kostecki and Olivier Naray to capture the activities relating to trade, investment, tourism and business advocacy, as well as results of studies on the connection between diplomacy and economics by Andrew K. Rose and Peter A.G. van Bergeijk. By creating smaller but more numerous consulates any country can decentralize representation, while strengthening its influence in important localities throughout the world (thereby enabling a direct link between the sending nation and trading hubs, as well as creating opportunities for bilateral trade and investments), Stringer (n 2) 75 and 76.

${ }^{52}$ More about the possible conflicts of interest, see Gawłowicz (n 3) $158 \mathrm{ff}$.
} 